\title{
HUBUNGAN ANTARA KEMATANGAN EMOSI DENGAN PERILAKU AGRESIF PADA SISWA SMK
}

\author{
Deis Natalia Sabintoe ${ }^{1}$, Christiana Hari Soetjiningsih ${ }^{2}$ \\ Fakultas Psikologi Universitas Kristen Satya Wacana Salatiga \\ deysn44@gmail.com
}

\begin{abstract}
This study aims to determine the relationship between emotional maturity with aggressive behavior in vocational students. This research was conducted on SMK students of class XI. The research sample of 63 students with saturated sampling technique. This type of research used in this study is a quantitative study with data collection procedures using a psychological scale that is the scale of emotional maturity from Katkhovsky and Gorlow (1976) totaling 47 items and the scale of aggressive behavior from Buss and Perry (1992) totaling 29 items. Statistical data analysis using Pearson Product Moment Analysis Test with the help of SPSS Statistics 16.0 for windows. The correlation coefficient obtained was -0.240 with a significance value of 0.029 ( $p<0.05)$. These results indicate that the hypothesis proposed by researchers, namely there is a negative relationship between emotional maturity with aggressive behavior in vocational students can be accepted. The negative correlation coefficient value indicates that the direction of the relationship between the two variables is negative, meaning that the higher the emotional maturity, the lower the aggressive behavior.
\end{abstract}

Keywords: Emotional Maturity, Aggressive Behavior

\begin{abstract}
Abstrak
Penelitian ini bertujuan untuk mengetahui adanya hubungan antara kematangan emosi dengan perilaku agresif pada siswa SMK. Penelitian ini dilakukan pada siswa SMK kelas XI. Sampel penelitian berjumlah 63 siswa dengan teknik sampling jenuh. Jenis penelitian yang digunakan dalam penelitian ini merupakan penelitian kuantitatif dengan prosedur pengumpulan data mengunakan skala psikologi yaitu skala kematangan emosi dari Katkhovsky dan Gorlow (1976) berjumlah 47 item dan skala perilaku agresif dari Buss dan Perry (1992) berjumlah 29 item. Analisis data statistik menggunakan Uji Analisis Pearson product Moment dengan bantuan SPSS Statistics 16.0 for windows. Koefisien korelasi yang diperoleh sebesar -0,240 dengan nilai signifikansi sebesar 0,029 ( $\mathrm{p}<0,05)$. Hasil tersebut menunjukkan bahwa hipotesis yang diajukan peneliti, yaitu terdapat hubungan negatif antara kematangan emosi dengan perilaku agresif pada siswa SMK dapat diterima. Nilai koefisien korelasi negatif menunjukkan bahwa arah hubungan kedua variabel adalah negatif, artinya semakin tinggi kematangan emosi maka semakin rendah perilaku agresif.
\end{abstract}

Kata kunci: Kematangan Emosi, Perilaku Agresif

PENDAHULUAN

Masa remaja merupakan masa transisi yaitu peralihan dari masa kanakkanak menuju masa dewasa. Masa transisi ini kemungkinan dapat menimbulkan masa krisis, karena belum adanya pegangan yang dimiliki para remaja dan kepribadiannya juga sedang mengalami pembentukan. Pada masa remaja, seseorang akan mengalami banyak perubahan dan masalah yang akan dihadapi dalam hidupnya (Hurlock, 1980). Perubahan yang dilalui remaja adakalanya menyebabkan remaja sulit menerimanya, apabila tidak sesuai dengan harapan remaja mencari pelarian dari keadaan yang tidak menyenangkan dengan mencari perhatian, melakukan hal-hal negatif. 
Remaja cenderung menilai sesuatu dan bertindak atas pandangan dan penilaiannya sendiri (Mussen, 2006).

Elida (2006) menjelaskan pada periode remaja individu cenderung memunculkan emosi negatif, hal ini karena remaja mengalami berbagai masalah dalam memenuhi kebutuhannya. Saat remaja mengalami situasi yang tidak menyenangkan, remaja akan cenderung menghadapinya dengan emosi negatif bahkan agresif (Kartono, 2005; Tengah, 2009).

Bentuk umum perilaku agresif adalah bertindak kasar sehingga menyakiti hati orang lain, suka berkelahi, membuat kegaduhan dalam masyarakat atau sekolah, mengolok-olok secara berlebihan, mengabaikan perintah, melanggar peraturan, sering berbohong, sering memerintah orang lain, sangat mementingkan diri sendiri, suka menyakiti hati anak yang lebih kecil atau lebih lemah dari dirinya, pendendam, suka melecehkan lawan jenis, dan lain sebagainya (Mappiare, 2004).

Berbagai bentuk perilaku agresif yang ditunjukkan remaja seringkali mendapatkan perhatian di kalangan masyarakat dan dunia pendidikan. Sebagai contoh kasus yaitu terjadi tawuran pelajar di Jakarta Antara pelajar SMA 70 dan
SMA 6 Jakarta di kawasan Bulungan. Tawuran terjadi ketika puluhan pelajar bentrok di sekitar Bulungan. Mereka saling lempar batu saling kejar di lokasi padat lalu lintas ini. Para pelajar ini juga membawa kayu dan bambu untuk saling serang (Wiangga, 2012). Kasus yang sama juga terjadi tawuran pelajar antara pelajar STM Penerbangan dan SMK Bakti mengalami luka-luka dibagian lengan kiri dan dipunggung belakang hingga menembus ke paru-paru. Sedangkan 6 pelajar dari STM Penerbangan yang membawa senjata tajam diserahkan ke Kejaksaan Negeri Jakarta Selatan (Kurniawan, 2012). Kasus lainnya yang terjadi, pada tanggal 13 Juni 2008 sekelompok remaja putri anggota Geng Nero menampar korbannya berulangulang. Beberapa korban yang berani mengungkapkan kelakuan Geng Nero adalah WD dan L, keduanya berusia 14 tahun, siswi kelas IX sebuah SMP di Kecamatan Juwana. Korban lain adalah LK. Anggota geng yang berhasil ditangkap adalah Rt, Yn, My, dan Tk. Keempatnya tercatat duduk di bangku kelas I SMA di Juwana. Geng itu sering menganiaya remaja putri, merekamnya lewat video telepon seluler (ponsel), dan kemudian mengedarkannya (Sutomo \& Yudha, 2008). 
Perilaku agresif peneliti temukan di salah satu Sekolah Menengah Kejuruan di Salatiga, informasi yang peneliti dapat dari salah satu guru BK permasalahannya antara lain berbicara tidak sopan terhadap kakak kelas, memusuhi teman yang berbeda pendapat, bertengkar dengan aksi pukul memukul karena saling beradu mulut dengan menjelek-jelekkan.

Pada suatu masyarakat, perilaku agresif adalah perilaku yang tidak disukai dan cenderung untuk dihindari. Hal ini karena perilaku tersebut menimbulkan bahaya dan ketidaknyamanan dalam berinteraksi sosial. Menurut Buss dan Perry (1992) perilaku agresif adalah keinginan untuk menyakiti orang lain, untuk mengekspresikan perasaan negatifnya seperti permusuhan untuk mencapai tujuan yang diinginkan.

Rahayu (2008) dalam penelitiannya juga menjelaskan bahwa perilaku agresif dipengaruhi oleh faktor internal dan faktor eksternal. Faktor internal, yakni faktor yang ada dalam diri seseorang yang berupa kematangan emosi yang kurang baik. Seseorang yang telah matang emosinya berarti dia mampu dalam mengendalikan luapan emosi dan nafsunya, sehingga seseorang tersebut dapat mengelolanya dengan baik. Sedangkan faktor eksternal yakni faktor yang berada dilingkungan sekitar yang berupa stimulus yang kurang baik yang diterima dari lingkungannya.

Menurut Rahayu (2008), setiap individu memiliki respon emosi yang berbeda-beda tergantung dari tingkat kematangan emosinya. Emosi marah yang bersifat negatif dan meledak-ledak disertai dengan faktor eksternal seperti frustrasi dan provokasi, menyebabkan terjadinya proses penyaluran energi negatif berupa dorongan agresif yang akan mempengaruhi perilaku individu. Individu dengan tingkat kematangan emosional tinggi mampu meredam dorongan agresif dan mengendalikan emosinya, pandai membaca perasaan orang lain, serta dapat memelihara hubungan baik dengan lingkungannya. Sehingga apabila individu memiliki kematangan emosi yang baik maka individu tersebut mampu untuk mengendalikan perilaku agresif nya

Kematangan emosi adalah kepribadian individu yang mampu untuk mengontrol atau mengendalikan emosinya dengan baik, termasuk cara pengungkapan dan mengatasi emosi tersebut (Hurlock, 2012). Katkovsky dan Gorlow (1976), mengatakan ciri-ciri orang yang telah matang emosinya memiliki kemandirian, kemampuan menerima kenyataan, kemampuan beradaptasi, kemampuan 
merespon dengan cepat, merasa aman, kemampuan berempati dan kemampuan menahan amarah.

Beberapa penelitian yang memperkuat keterkaitan kematangan emosi dengan agresif, antara lain Guswani dan Kawuryan (2011) pada mahasiswa daerah Kudus dengan metode teknik accidental sampling menyatakan bahwa ada hubungan negatif yang signifikan antara kematangan emosi dengan perilaku agresif pada mahasiswa. Syarif (2007) juga melakukan penelitian yang sama pada warga asrama di Samarinda menyatakan ada hubungan negatif yang signifikan antara kematangan emosi dan perilaku agresif. Bahwa kematangan emosi yang baik dapat mengendalikan perilaku agresif seseorang dan sebaliknya jika kematangan emosi buruk maka perilaku agresi seseorang semakin tidak terkontrol atau tidak dapat dikendalikan. Namun penelitian lain menyatakan hal yang berbeda dari kedua penelitian sebelumnya, penelitian yang dilakukan Reena (2018) pada remaja awal di Kabupaten Kanyakumari-India menyatakan bahwa tidak ada hubungan yang signifikan antara kematangan emosi dengan perilaku agresif remaja awal.

Berdasarkan hasil-hasil penelitian yang belum konklusif dimana masih terdapat perbedaan hasil penelitian yang mengatakan ada hubungan dan tidak ada hubungan antara kematangan emosi dan perilaku agresif, maka peneliti ingin melakukan penelitian lanjut tentang apakah ada hubungan antara kematangan emosi dengan perilaku agresif pada siswa SMK.

\section{METODE PENELITIAN}

Metode yang digunakan dalam penelitian ini merupakan metode penelitian kuantitatif. Pengumpulan data dalam metode ini menggunakan skala. Alat ukur yang digunakan yaitu skala kematangan emosi dan skala perilaku agresif dengan menggunakan skala model likert. Subjek dalam penelitian ini siswa SMK kelas XI berjumlah 63 orang yang berusia 15-18 tahun. Pengambilan sampel dalam penelitian ini dilakukan dengan teknik sampling jenuh, yaitu teknik pengambilan sampel dengan mengambil semua populasi untuk menjadi sampel (Sugiyono, 2007). Teknik analisis data yang digunakan untuk melihat ada tidaknya hubungan Antara kematangan emosi dengan perilaku agresif, peneliti menggunakan korelasi Pearson-product moment.

\section{HASIL DAN PEMBAHASAN}

Berdasarkan hasil perhitungan batas bawah (skor minimum) dan batas atas 
(skor maksimum), hasil tersebut dimasukkan kedalam interval kategorisasi tiap variabel yang dilihat dalam 4 kategori, sangat tinggi, tinggi, rendah dan sangat rendah.

\section{Kematangan Emosi}

Dalam variabel kematangan emosi memiliki item dengan daya diskriminasi baik berjumlah 39 item. Berdasarkan hasil analisis dari variabel kematangan emosi diperoleh siswa yang berada pada kategori sangat tinggi berjumlah 3 siswa dengan presentase sebesar $4,76 \%$, pada kategori tinggi berjumlah 41 siswa sebesar $65,08 \%$, pada kategori rendah berjumlah 18 siswa sebesar 28,57\%, dan pada kategori rendah berjumlah 1 siswa sebesar $1,59 \%$. Berdasarkan data diatas dapat juga dilihat bahwa siswa rata-rata memiliki kematangan emosi tergolong tinggi yaitu 104,71. Skor siswa bergerak dari skor minimum 64 dan skor maximum 133.

Tabel 1 Kategorisasi Kematangan Emosi

\begin{tabular}{|c|c|c|c|c|c|}
\hline N0 & Interval & Kategori & $\mathrm{N}$ & $\%$ & Mean \\
\hline 1 & $126,75<X \leq 156$ & Sangat Tinggi & 3 & $4,76 \%$ & \multirow{5}{*}{104,71} \\
\hline 2 & $97,5<X \leq 126,75$ & Tinggi & 41 & $65,08 \%$ & \\
\hline 3 & $68,25<X \leq 97,5$ & Rendah & 18 & $28,57 \%$ & \\
\hline 4 & $39<X \leq 68,25$ & Sangat Rendah & 1 & $1,59 \%$ & \\
\hline Jumlah & & & 63 & $100 \%$ & \\
\hline
\end{tabular}

Tabel 2 Kategorisasi Perilaku Agresif

\begin{tabular}{llllll}
\hline N0 & Interval & Kategori & N & $\%$ & Mean \\
\hline 1 & $68,25 \square X \square 84$ & Sangat Tinggi & 4 & $6,35 \%$ & 53,78 \\
\hline 2 & $52,5 \square X \square 68,25$ & Tinggi & 34 & $53,97 \%$ \\
\hline 3 & $36,75 \square X \square 52,5$ & Rendah & 19 & $30,16 \%$ \\
\hline 4 & $21 \square X \square \square 36,75$ & Sangat Rendah & 6 & $9,52 \%$ \\
\hline Jumlah & 63 & $100 \%$ \\
\hline \multicolumn{5}{c}{ SD $=10,89$, Min = 31, Max $=80$} \\
\hline \multicolumn{5}{c}{} \\
\hline \multicolumn{5}{c}{}
\end{tabular}

\section{Perilaku Agresif}

Dapat dilihat pada tabel 2, dalam variabel perilaku agresif memiliki item dengan daya diskriminasi baik berjumlah 21 item. Berdasarkan hasil analisis dari variabel perilaku agresif diperoleh siswa yang berada pada kategori sangat tinggi berjumlah 4 siswa dengan presentase 6,35\%, pada kategori tinggi sebanyak 34 siswa dengan presentase sebesar 53,97\%, pada kategori rendah sebanyak 19 siswa sebesar 30,16\% dan sangat rendah sebanyak 6 siswa sebesar 9,52\%. Berdasarkan data diatas juga dilihat bahwa siswa rata-rata memiliki perilaku agresif tergolong rendah yaitu 53,78. Skor siswa bergerak dari skor minimum 31 dan skor maximum 80.

\section{Uji Asumsi}

Sebelum melakukan uji korelasi sebagaimana tujuan penelitian ini, peneliti melakukan uji asumsi terlebih dahulu yang terdiri dari uji normalitas dan uji linearitas. 


\section{Uji Normalitas}

Uji normalitas yaitu untuk mengetahui apakah data dalam penelitian berdistribusi normal atau tidak. Data dapat dikatakan berdistribusi normal apabila nilai signifikansi (nilai probabilitas $=p$ ) lebih dari 0,05 (Santoso, 2002). Berdasarkan hasil perhitungan uji Kolmogorov-smirnov $\mathrm{Z}$ diperoleh besar nilai K-S-Z variabel kematangan emosi sebesar 0,572, n.signifikansi 0,899 ( $p>0,05)$ dan nilai K-S-Z variabel perilaku agresif sebesar 0,956, n.signifikansi 0,320 ( $>>0,05)$, dari data tersebut artinya kedua variabel tersebut berdistribusi normal.

\section{Uji Linearitas}

Hasil uji linearitas dilakukan untuk mengetahui linearitas hubungan antara variabel kematangan emosi dan variabel perilaku agresif dan untuk mengetahui signifikansi penyimpangan dari linearitas hubungan tersebut. Hasil uji linearitas menunjukkan adanya hubungan yang linear antara kematangan emosi dan perilaku agresif dengan deviation from linearity sebesar $\mathrm{F}$ beda $=1,286, \mathrm{P}=$ $0,261(\mathrm{p}>0,05)$.

\section{Uji Korelasi}

Berdasarkan hasil pengujian yang dilakukan korelasi sebesar -0,240 dengan nilai signifikansi sebesar $0,029(\mathrm{p}<0,05)$ yang berarti ada hubungan yang negatif dan signifikan antara kematangan emosi dan perilaku agresif pada siswa SMK, artinya hal ini menunjukkan bahwa hipotesis yang diajukan dalam penelitian ini diterima. Makin tinggi kematangan emosi maka makin rendah perilaku agresif sebaliknya makin rendah kematangan emosi maka makin tinggi perilaku agresifnya.

Berdasarkan hasil penelitian mengenai kematangan emosi dengan perilaku agresif pada siswa SMK, terdapat adanya hubungan negatif signifikan. Berdasarkan dari koefisien korelasi $(\mathrm{r})=$ 0,240 dengan signifikansi 0,029 $(\mathrm{p}<0,05)$. Hal ini sesuai dengan hipotesis yang diajukan penulis yaitu hubungan yang negatif dan signifikan antara kematangan emosi dan perilaku agresif pada siswa SMK. Hasil tersebut menunjukkan bahwa semakin tinggi kematangan emosi maka semakin rendah perilaku agresif, sebaliknya semakin rendah kematangan emosi maka semakn tinggi perilaku agresif pada siswa.

Hal ini sesuai dengan hasil penelitian yang dilakukan Winarsih (2007) mengenai hubungan antara kematangan emosi dengan perilaku agresif. Hasil analisis data diperoleh hasil koefisien korelasi $-0,633$ dapat disimpulkan bahwa ada hubungan yang 
terjadi cukup erat. Nilai koefisien korelasi adalah negatif berarti semakin tinggi kematangan emosi maka diperkirakan skor perilaku agresif orang tersebut akan semakin rendah.

Hasil penelitian ini sesuai teori yang dikemukakan Hurlock (2012) yang menyatakan bahwa kematangan emosi adalah suatu keadaan atau kondisi mencapai tingkat kedewasaan dari perkembangan emosional sebab itu seseorang tidak lagi menampilkan pola emosional yang seperti anak-anak, namun mereka mampu mengontrol emosi lebih baik khususnya ketika berada di situasi sosial. Dengan demikian seseorang yang mempunyai kematangan emosi yang tinggi mampu menampilkan pola emosional yang pantas dengan masa perkembangannya, mampu mengelola emosinya dengan baik dan memenuhi karakteristik individu yang matang emosinya seperti dapat beradaptasi dengan baik, kemampuan berempati, dan pengendalian amarah yang baik tanpa menyakiti orang lain.

Hasil penelitian ini juga mendukung pendapat Rahayu (2008) bahwa emosi marah yang bersifat negatif dan meledakledak disertai faktor eksternal seperti frustasi dan provokasi, menyebabkan terjadinya proses penyaluran energi negatif berupa dorongan agresif yang akan mempengaruhi perilaku individu. Individu dengan tingkat kematangan emosi yang tinggi mampu meredam dorongan agresif dan mengendalikan emosinya, pandai membaca perasaan orang lain, serta dapat memelihara hubungan baik dengan lingkungannya, sehingga apabila individu memiliki kematangan emosi yang baik maka individu tersebut mampu mengendalikan perilaku agresifnya.

Pembahasan yang telah dijelaskan diatas menunjukkan bahwa perilaku agresif dapat ditekan jika setiap individu memiliki kematangan emosi yang baik. Kematangan emosi yang baik akan memandu individu untuk mengarahkan perilakunya dengan kuat yang akhirnya menuju kedalam konsekuensi yang positif, sehingga siswa terhindar dari perilaku agresif yang tidak sesuai dengan norma yang berlaku di masyarakat.

\section{KESIMPULAN}

Terdapat hubungan negatif signifikan antara kematangan emosi dan perilaku agresif pada siswa SMK. Makin tinggi kematangan emosi maka makin rendah perilaku agresif sebaliknya makin rendah kematangan emosi maka makin tinggi perilaku agresifnya.Sumbangan kematangan emosi terhadap perilaku agresif sebesar 57\% sedangkan sisanya 
43\% dipengaruhi oleh variabel diluar penelitian. Sebagian besar siswa $(65,08 \%)$ mempengaruhi kematangan emosi pada kategori tinggi dan sebagian besar $(30,16 \%)$ perilaku agresifnya pada kategori rendah.

\section{SARAN}

Berdasarkan hasil penelitian diatas, maka peneliti memberikan beberapa saran, sebagai berikut; bagi sekolah diharapkan membantu siswa didiknya untuk mencapai perkembangan kematangan emosi dengan cara mengadakan kegiatan-kegiatan dan pelatihan-pelatihan yang meningkatkan emosi seperti kegiatan ekstrakurikuler. Bagi siswa yang memiliki kematangan emosi rendah dengan perilaku agresif tinggi diharapkan dapat meningkatkan kemampuan emosinya dengan belajar untuk mengendalikan emosi, serta berusaha berpikir positif sehingga dapat mengrontrol emosi agar tidak berperilaku agresif terhadap orang lain. Sedangkan bagi siswa yang memiliki kematangan emosi yang baik dibanding perilaku agresifnya agar dapat mempertahankan kematangan emosinya sehingga tidak bertindak agresif terhadap orang lain.

Penelitian ini masih belum sempurna dan masih memiliki kekurangan sehingga peneliti memiliki saran untuk penelitian selanjutnya yaitu bagi peneliti yang ingin meneliti variabel yang sama diharapkan dapat mengungkap lebih dalam dengan meningkatkan kualitas hasil penelitian dengan lebih memperluas populasi, melengkapi dengan teknik pengumpulan data yang lain atau menyertakan variabel dari faktor-faktor lain selain kematangan emosi seperti kecerdasan emosional, pengaruh media massa, obat-obatan terlarang, religiusitas, dan kontrol diri.

\section{DAFTAR PUSTAKA}

Buss, A. H., \& Perry, M. P. (1992). The aggression questionnaire. Journal of Personality and Social Psychology, 63, 452-459.

Elida, P. (2006). Psikologi perkembangan remaja. Padang: Angkasa Raya.

Geng Nero Ditangkap. (2018). Retrived November 21, 2018, from http:/www.jawapos.co.id/halaman/ detail\# id=556311..

Guswani, A. M., \& Kawuryan, F. (2011). Perilaku agresi pada mahasiswa ditinjau dari kematangan emosi. Jurnal Psikologi Pitutur, 1, 86-93.

Hurlock, E. B. (1980). Psikologi perkembangan suatu pendekatan sepanjang rentan kehidupan. Jakarta: Erlangga. Edisi Kelima.

Hurlock, E.B. (2012). Psikologi perkembangan (Terjemahan: Istiwidayanti Soedjarwo). Jakarta: Erlangga. 
Kartono, M. (2005). Perbandingan perilaku agresif antara remaja yang berasal dari keluarga bercerai dengan keluarga utuh. Jurnal Psikologi 3(1), 1

Katkovsky, W., \& Gorlow, L. (1976). The psychology of adjustment: current concepts and applications. McGraw-Hill Companies.

Mappiare, A. (2004). Pengantar konseling dan psikoterapi. Jakarta: PT Raja Grafindo Persada.

Mussen, P.H. (2006). Perkembanan anak (Terjemahan Meitasari Tjandrasa). Jakarta: Erlangga.

Rahayu, C. D. (2008). Hubungan kematangan emosi dan konformitas dengan perilaku agresif pada supporter sepak bola. Surakarta: Universitas Muhammadiyah.

Reena R S. (2018). Aggressive behaviour and emotional maturity of early adolescents. International Journal of Research - Granthaalayah, 6(10), 57-64.

Sugiyono. (2007). Metode penelitian pendidikan pendekatan kuantitatif, kualitatif, dan $R \& D$. Bandung: Alfabeta.

Syarif, F. (2017). Hubungan kematangan emosi dengan perilaku agresi pada mahasiswa warga asrama komplek asrama ayu sempaja. Psikoborneo, 5, 267-280.

Tawuran pelajar di Jakarta Selatan. (2019). Retrived Januari 19, 2019, from

http://www.tribunnews.com/metrop olitan/2012/10/11/lagi-tawuranpelajar-terjadi-di-jakarta-selatan

Tawuran SMA 6 vs SMA 70. (2019). Retrived Januari 20, 2019, from https://kabar24.bisnis.com/read/201 20926/79/97557/tawuran-sma-6 vssma-70 perkelahian-pelajar-dibulungan-sudah-jadi-tradisi mengapa.

Tengah, A. K. J. (2009). Perilaku agresif ditinjau dari persepsi pola asuh authoritarian, asertivitas dan tahap perkembangan remaja pada anak binaan lembaga pemasyarakatan. Humanitas, 6(1), 11-25 